\title{
Historical Sociology and the Arab Uprising
}

\author{
Raymond Hinnebusch \\ Mediterranean Politics, 19:1, 2014, 137-140 \\ DOI: $10.1080 / 13629395.2013 .856180$
}

Historical sociology (HS) is well positioned to analyze the impact of the Arab Uprising on Middle East states; indeed, Ibn Khaldoun, one of its precursors, pioneered our understanding of MENA state formation. In the positivist tradition of material/structural analysis, it has several advantages over its main rival for understanding the Uprising, democratization theory (DT).

First, it posits the co-constitution of the inter/trans-national and the state levels. Thus, it traces the impact of long-term macro transformations on state formation, as in Barrington Moore's (1966) analysis of how agricultural modernization shaped dictatorship and democracy and Tilly's (1990) account of how war-making drove state formation in the West; in parallel, its Weberian strain (e.g. Mann 1984) focuses on shorter-term internal state building processes, such as the cycle between charismatic and patrimonial leadership, and the interaction of political participation and institutionalization (Huntington 1968).

Second, HS eschews teleological assumptions of a universal democratic end point of development. For, if modernization theory identified a law of increasing politicization driven by socio-economic modernization, classical political sociology's "Iron Law of Oligarchy" (Michels 1966), exposed the practices used to sustain elite or class rule in spite of this (and regardless of competitive elections): elites' disproportionate resources (information, wealth), command of the levers of bureaucracies and relative cohesion compared to the divided, usually inactive and inattentive public. Similarly, while revolutionary periods feature exceptional mass activism, such mobilization cannot be sustained, especially if revolutions are merely political turnovers, leaving the distribution of property intact. Thus, rather than linear "progress" toward mass empowerment, HS expects an on-going struggle of oligarchic and democratic tendencies.

Third, instead of DT's one-dimensional dichotomization of states into simple authoritarian and democratic opposites, HS expects actually existing regime types to be variegated along two separate dimensions, elite contestation and mass inclusion, which may not vary together: thus, high elite contestation and low mass inclusion was typical of landed oligarchy while under populist republics a contraction of contestation was enabled by an expansion of mass inclusion, only to be later followed in "post-populist" republics by a contraction of inclusion (Hinnebusch 2010). Moreover, continuums better capture the actual political world than dichotomies, with hybrid regimes common in which elite dominance is qualified by episodes of elite contestation and mass mobilization. This is likely to be the outcome of the Arab Uprising.

Fourth, for HS, states' tangents are understood, not according to what abstract or normative theories expect, but on the basis of path dependency-how the past shapes the future, with the inertia of "successful" institutional solutions closing off some possibilities, making other more likely (Mahoney 2000). Yet, since the past is the outcome of contingent agency, state formation tangents are historically specific, varying by region and between early and late developers. 


\section{Illustrating HS in Action:}

The utility of HS can be illustrated by a brief sketch of how an understanding of the evolution of the MENA states system, co-constituted by external and internal forces, along path dependent tangents, contextualizes the Arab Uprising. The states system created under Western imperialism suffered from built-in flaws, notably lack of congruence between sub and supra-state identities and newly created states with often-artificial boundaries, hence pervaded with irredentism. The region's subsequent development reflected attempts by state builders to find solutions to these flaws. State builders interacted with macro-level trends such as de-colonization and globalization to produce variegated hybrids of patrimonial and institutional authority. The agency of earlier phases created durable but suboptimal structural outcomes whose costs stimulated further agency, and so on, with the Arab Uprising a symptom of the ultimate failure to create strong states.

Several distinct phases in MENA state formation can be identified. The Age of Liberal Oligarchy (1920-70) was dominated by oligarchic regimes still under British hegemony and economically dependent. With formally liberal elite contestation but little mass inclusion, they faced revolt from the emerging middle class and peasantry. The Age of Pan-Arab Revolution (1950-70) was a reaction to oligarchy and imperialism enabled by global decolonization. PanArab movements unleashed praetorian instability (army coups, student revolts) but in Egypt Nasser forged the prototype of the populist authoritarian republic that narrowed elite contestation while expanding mass inclusion through redistributive social policies and national economic development. Nasser exploited Soviet protection and Pan-Arabism to roll back British hegemony in the name of an autonomous Arab region but his defeat in the 1967 Arab-Israeli war marked the failure of this project. In the Age of Realism (1970-90) a relative consolidation of the state resulted from state builders' efforts to counter praetorianism, war preparation and the expansion of oil rent. Republics and monarchies converged through similar neo-patrimonial practices combining elite assabiyya, modern bureaucracy and clientalism. Wars generated security dilemmas, provoking realist power balancing via arms races and alliance formation. The Age of Post-Populist Dependency (1990-2010) was a consequence of the global triumph of neo-liberal capitalism over socialism, combined with the overdevelopment/over-militarization of regional states relative to their economic bases, exposed with the oil price bust, resulting in debt, economic crisis, economic liberalization and openings to the West. The consequent favouring of crony capitalists and foreign investors and exclusion of the masses, ushered in "post populist authoritarianism," with political Islam mobilizing the marginalized. The outcomes of the Arab Uprising are path dependent products of this heritage.

HS also allows us to better understand the Arab Uprising. At the macro level, the Uprising was a function of how neo-liberal globalization had both driven post-populist mass exclusion and also promoted democracy discourse and Internet technology that encouraged anti-regime mobilization. The Uprising unleashed both elite contestation and mass political mobilization, in which the overthrow of authoritarian presidents, weakening of state establishments and initial empowerment of Islamist outsiders appeared to reverse inherited 
hierarchies. However, revived oligarchic tendencies soon undermined mass empowerment. International finance capital, locking governments into neoliberal practices, excluded the big issue of revolutionary politics-redistribution of wealth--from political agendas. With post-Uprising elites, regardless of ideological orientation, constrained by economic dependency, elections offered limited policy choices, hence political competition has been diverted into cultural wars that sharply divided the masses.

Indeed, mass mobilization unleashed trans-state wars over identity, but rather than the inclusive, egalitarian Pan-Arab identity Nasser had promoted, highly divisive Sunni vs. Shia, secular vs. Islamist discourses dominated. The Gulf monarchies, local manifestations of global finance capital, were empowered as Uprisings opened the republics to penetration by their petrodollars, arms and salafi ideologies, while the republics, especially multi-sectarian Syria, Iraq and Lebanon, were destabilized.

Finally, the Uprising unleashed a new deeper wave of "praetorianism" as political mobilization exceeded institutionalization and politics was played via street protests and military intervention, as well as elections, without agreed rules of the game (Huntington 1968). The masses were now a key resource in intra-elite power struggles between state establishments, liberal secularists and Islamists. Where the central power survived, hybrid regimes combined authoritarian exclusion with elections in which rivals used identity politics to mobilize constituencies; where it collapsed, mass praetorianism took the form of armed social movements and warlords, as in Libya and Syria.

In summary, variegated regimes mixing oligarchic and democratic tendencies are being co-constituted by international and internal forces, along paths dependent on the region's historical inheritance.

\section{Conclusion:}

HS, possibly handicapped by its relative prioritization of structure over agency and ideas, did not, of course, anticipate the occasion of the Uprising, specifically the ability of internet-armed youth to destabilize durable regimes. Yet, as path dependency tells us, the Uprising was not only a reaction against what came before, but is also constrained by this prior inheritance; thus, the incongruity between the idea of democracy and durable oligarchic material structuresmilitary institutions, international finance capital-resulted in consequences quite unintended by revolutionary agents, much as the "iron law of oligarchy" suggests. Several other HS-inspired analyses have reached similar conclusions: Zubaida (2011) saw the Uprising reproducing MENA's historical cycles of political activism and patrimonialism while Lawson (2012) identified global structural constraints on revolutionary agency. Because the Arab Uprising has not re-written the basic rules of political life, "old" HS tools of analysis remain as relevant as ever.

\section{References}

Hinnebusch, Raymond (2010) "Towards a Sociology of State Formation in the Middle East, Middle East Critique, 19:3, pp. 201-16

Huntington, Samuel (1968) Political Order in Changing Societies (New Haven: Yale University Press). 
Lawson, George (2012) "After the Arab Spring: Power shift in the Middle East," LSE Research Online, http://eprints.lse.ac.uk/43455/

Mahoney, James (2000) "Path Dependence in Historical Sociology," Theory and Society, 29:4, pp. 507-48

Mann, Michael (1984) "The autonomous power of the state: its origins, mechanisms and results," European Journal of Sociology, 25, pp. 185-213

Michels, Robert (1966) Political Parties: A Study of the Oligarchical Tendencies of Modern Democracy (New York: Free Press).

Moore, Barrington (1966) The Social Origins of Dictatorship and Democracy (Boston: Beacon Press).

Tilly, Charles (1990). Coercion, Capital, and European States, AD 990-1990. Cambridge, Mass., USA: B. Blackwell, 1990.

Zubaida, Sami (2011) The "Arab spring" in historical perspective Open Democracy, 21 October, http://www.opendemocracy.net/sami-zubaida/arab-spring-in-historicalperspective 